\title{
Adoption of Integrated Pest Management Practices for Control of Pink Bollworm by Cotton Growers
}

\author{
Shital Mane* , P. P. Wankhade and Vaishali Rane \\ Department of Extension Education, College of Agriculture, Nagpur, India \\ *Corresponding author
}

\section{A B S T R A C T}

\begin{tabular}{l} 
K e y w o r d s \\
$\begin{array}{l}\text { Knowledge, } \\
\text { Adoption, Cotton } \\
\text { growers }\end{array}$ \\
Article Info \\
$\begin{array}{l}\text { Accepted: } \\
16 \text { November } 2020 \\
\text { Available Online: } \\
\text { 10 December } 2020\end{array}$ \\
\hline
\end{tabular}

\section{Introduction}

The world textile industries are being ruled by "King Cotton". The antiquity of cotton has been traced to the fourth millennium BC. The fabric pieces from "Mohenjodaro" excavations were found to made up of cotton. For over three thousand's years (1500BC to 1700 AD) India was recognized as cradle of cotton industry. India was country in the world to domesticate cotton and utilize its fibre to manufacture fabric. India is the second largest producer of cotton in the world. India accounts for approximately 25 per cent of world's cotton area and 16 per cent of total cotton production. Maharashtra is the important cotton growing state in India with 31.33 lakh ha and production of 62.00 lakh bales.

Integrated Pest Management is a pest management system hat in the content of the associated environment and the pest population dynamics of the pest species. Utilize all suitable techniques and methods in as compatible manner as possible and maintain the pest population at the level below these causing economic injury. This approach has been maintaining the agro-ecosystem. It has more relevant due to advantage like safely to environment, pesticide-free food commodities, low input based crop production. 


\section{Materials and Methods}

The study was conducted in Nagpur district of Maharashtra State. Out of 14 talukas of Nagpur district namely, Hingna and Nagpur (Rural) talukas were purposively selected for the study. Five villages were selected purposively from each taluka considering the maximum area under cotton cultivation. Thus in total, ten villages were taken for the study and a total of 120 respondents were selected. The exploratory research design was used for the study. The data were collected in face-toface situation by the personal interview method with the help of structured interview schedule containing the questions on adoption of integrated pest management practices for control of pink bollworm. The data were tabulated, analyzed and the results were interpreted as on Table 1 .

\section{Results and Discussion}

The findings of the study had been presented under the following headings.

\section{Knowledge of integrated pest management practices by the cotton growers}

The data in table 1 practice wise knowledge of respondents about cultural method of integrated pest management, cent per respondents(100\%) had knowledge about allowing cattle grazing on the left over green bolls of the plant at the end of crop season, deep ploughing during summer(89.16\%), timely sowing $(80.84 \%$ ) and selection of recommended variety with early medium maturity $(47.50 \%)$, respectively. Regarding mechanical method, most of the respondents had knowledge about destruction of cotton stubbles immediate after by harvest $(81.66 \%)$, followed by use of pheromone traps (61.66\%) and hand picking and destruction of larvae $(60.00 \%)$, respectively. In case of biological method majority of the respondents were having knowledge about spraying of Neem Seed Kernel Extract (N.S.K.E.) 5\% during flowering stage $(56.67 \%)$ and Use of trichocards $(40.00 \%)$, of chloropyriphos 20 ml/10lit. / quinolphos 20ml/10lit / profenophos $20 \mathrm{ml} / 10$ lit / thiodicarb 20 $\mathrm{gm} / 10$ lit at initial stage of $\operatorname{ETL}(87.50 \%)$, followed by avoid mixing of agrochemicals(65.00\%) and use of synthetic pyrethroides (Cypermetherium $10 \mathrm{ml} / 10$ lit and Fenvelrate $8 \mathrm{ml} / 10$ lit) and combination product $(63.34 \%)$, respectively. It could revealed that majority of respondents have knowledge about application

\section{Adoption of integrated pest management practices by cotton growers}

The table 1 concluded that the adoption of integrated pest management practices of cotton, it was found that the majority of respondents completely adopted integrated pest management practices like to cultural methods under integrated pest management practices, most of the practices were completely adopted by respondents such as, cultural methods were allowing cattle grazing on the left over green bolls of the plant at the end of crop season (71.67\%).In case of complete adoption of IPM practices under mechanical method, destruction of cotton stubbles immediate after by harvest (36.66\%). Regarding with biological method, above one fourth of cotton growers completely adopted method such as spraying of Neem Seed Kernel Extract (N.S.K.E.) 5\% during flowering stage $(27.50 \%)$. It may also seen that of complete adoption of chemical methods like application of chloropyriphos 20 ml/10lit. / quinolphos 20ml/10lit / profenophos $20 \mathrm{ml} / 10$ lit / thiodicarb 20 $\mathrm{gm} / 10$ lit at initial stage of ETL (43.34\%).

Whereas most of respondents partially adopted cultural methods of integrated pest management practices were, timely sowing 
(60.00\%), deep ploughing during summer $(30.00 \%)$. However, it was observed that the majority of the respondents partially adopted mechanical method, destruction of cotton stubbles immediate after by harvest (45.00\%), hand picking and destruction of larvae $(40.00 \%)$. Moreover, the others partially adopted biological methods like spraying of Neem Seed Kernel Extract (N.S.K.E.) 5\% during flowering stage $(29.16 \%)$ were adopted by the respondents partially. Regarding chemical method, most of the respondents partially adopted methods like, application of chloropyriphos $20 \mathrm{ml} / 10 \mathrm{lit}$. / quinolphos 20ml/10lit / profenophos $20 \mathrm{ml} / 10$ lit / thiodicarb $20 \mathrm{gm} / 10$ lit at initial stage of $\operatorname{ETL}(56.66 \%)$.

Table.1 Distribution of respondents according to their recommended practice wise knowledge and adoption of integrated pest management practices

\begin{tabular}{|c|c|c|c|c|c|c|}
\hline \multirow[t]{3}{*}{$\begin{array}{l}\text { Sl. } \\
\text { No. }\end{array}$} & \multirow[t]{3}{*}{ IPM practices } & \multicolumn{2}{|c|}{$\begin{array}{c}\text { Knowledge } \\
(\mathbf{n}=120)\end{array}$} & \multicolumn{3}{|c|}{$\begin{array}{c}\text { Adoption } \\
(\mathbf{n}=120)\end{array}$} \\
\hline & & $\begin{array}{l}\text { Yes } \\
\text { (1) }\end{array}$ & $\begin{array}{l}\text { No } \\
\text { (0) }\end{array}$ & $\begin{array}{l}\text { CP } \\
(2)\end{array}$ & $\begin{array}{l}\text { PA } \\
\text { (1) }\end{array}$ & $\begin{array}{l}\text { NA } \\
(\mathbf{0})\end{array}$ \\
\hline & & $\begin{array}{c}\text { Freq. } \\
(\%)\end{array}$ & $\begin{array}{c}\text { Freq. } \\
(\%)\end{array}$ & $\begin{array}{c}\text { Freq. } \\
(\%)\end{array}$ & $\begin{array}{c}\text { Freq. } \\
(\%)\end{array}$ & $\begin{array}{c}\text { Freq. } \\
(\%)\end{array}$ \\
\hline A. & Cultural Method & & & & & \\
\hline 1. & Deep ploughing during summer & $\begin{array}{c}107 \\
(89.16)\end{array}$ & $\begin{array}{c}13 \\
(10.84)\end{array}$ & $\begin{array}{c}71 \\
(59.14)\end{array}$ & $\begin{array}{c}36 \\
(30.00)\end{array}$ & $\begin{array}{c}13 \\
(10.86)\end{array}$ \\
\hline 2 & Timely sowing (Avoid pre monsoon sowing) & $\begin{array}{c}97 \\
(80.84)\end{array}$ & $\begin{array}{c}23 \\
(19.16)\end{array}$ & $\begin{array}{c}23 \\
(19.16)\end{array}$ & $\begin{array}{c}72 \\
(60.00)\end{array}$ & $\begin{array}{c}25 \\
(20.84)\end{array}$ \\
\hline 3 & $\begin{array}{l}\text { Selection of recommended variety with early medium } \\
\text { maturity.(140 to } 160 \text { days duration and resistance to } \\
\text { sucking pest) }\end{array}$ & $\begin{array}{c}57 \\
(47.50)\end{array}$ & $\begin{array}{c}63 \\
(52.50)\end{array}$ & $\begin{array}{c}35 \\
(29.16)\end{array}$ & $\begin{array}{c}22 \\
(18.34)\end{array}$ & $\begin{array}{c}63 \\
(52.50)\end{array}$ \\
\hline 4 & $\begin{array}{l}\text { Allowing cattle grazing on the left over green bolls of the } \\
\text { plant at the end of crop seas }\end{array}$ & $\begin{array}{c}120 \\
(100)\end{array}$ & $\begin{array}{c}00 \\
(00)\end{array}$ & $\begin{array}{c}86 \\
(71.67)\end{array}$ & $\begin{array}{c}34 \\
(28.33)\end{array}$ & $\begin{array}{c}00 \\
(00)\end{array}$ \\
\hline B & Mechanical Method & & & & & \\
\hline 5 & Hand picking and destruction of larvae. & $\begin{array}{c}72 \\
(60.00)\end{array}$ & $\begin{array}{c}48 \\
(40.00)\end{array}$ & $\begin{array}{c}24 \\
(20.00)\end{array}$ & $\begin{array}{c}48 \\
(40.00)\end{array}$ & $\begin{array}{c}48 \\
(40.00)\end{array}$ \\
\hline 6 & Destruction of cotton stubbles immediate after by harvest. & $\begin{array}{c}98 \\
(81.66)\end{array}$ & $\begin{array}{c}22 \\
(18.34)\end{array}$ & $\begin{array}{c}44 \\
(36.66)\end{array}$ & $\begin{array}{c}54 \\
(45.00)\end{array}$ & $\begin{array}{c}22 \\
(18.34)\end{array}$ \\
\hline 7 & $\begin{array}{l}\text { Use of pheromone traps ( } 2-3 \text { pheromone traps/acer) for } \\
\text { monitoring.(at the time of flowering) }\end{array}$ & $\begin{array}{c}74 \\
(61.66)\end{array}$ & $\begin{array}{c}46 \\
(38.34)\end{array}$ & $\begin{array}{c}41 \\
(34.16)\end{array}$ & $\begin{array}{c}33 \\
(27.50)\end{array}$ & $\begin{array}{c}46 \\
(38.34)\end{array}$ \\
\hline $\mathbf{C}$ & Biological Method & & & & & \\
\hline 8 & $\begin{array}{l}\text { Spraying of Neem Seed Kernel Extract (N.S.K.E.) } 5 \% \\
\text { during flowering stage. }\end{array}$ & $\begin{array}{c}68 \\
(56.67)\end{array}$ & $\begin{array}{c}52 \\
(43.33)\end{array}$ & $\begin{array}{c}33 \\
(27.50)\end{array}$ & $\begin{array}{c}35 \\
(29.16)\end{array}$ & $\begin{array}{c}52 \\
(43.34)\end{array}$ \\
\hline 9 & $\begin{array}{l}\text { Use of trichocards ( } 3 \text { cards/acre) i.e. for } 7-8 \text { times after the } \\
\text { initiation of flowers at an interval } 8-10 \text { days. }\end{array}$ & $\begin{array}{c}0 \\
(00)\end{array}$ & $\begin{array}{c}120 \\
(100.00)\end{array}$ & $\begin{array}{c}0 \\
(00)\end{array}$ & $\begin{array}{c}0 \\
(00)\end{array}$ & $\begin{array}{c}120 \\
(100.00)\end{array}$ \\
\hline $\mathbf{D}$ & Chemical Method & & & & & \\
\hline 10 & $\begin{array}{l}\text { Application of chloropyriphos } 20 \mathrm{ml} / 10 \text { lit. / quinolphos } \\
\text { 20ml/10lit / profenophos } 20 \mathrm{ml} / 10 \mathrm{lit} / \text { thiodicarb } 20 \\
\text { gm/10lit at initial stage of ETL. }\end{array}$ & $\begin{array}{c}105 \\
(87.50)\end{array}$ & $\begin{array}{c}15 \\
(12.50)\end{array}$ & $\begin{array}{c}52 \\
(43.34)\end{array}$ & $\begin{array}{c}68 \\
(56.66)\end{array}$ & $\begin{array}{c}0 \\
(00)\end{array}$ \\
\hline 11 & $\begin{array}{l}\text { Avoid mixing of agrochemicals. (Monocrotophos + } \\
\text { Acephate) }\end{array}$ & $\begin{array}{c}78 \\
(65.00)\end{array}$ & $\begin{array}{c}42 \\
(35.00)\end{array}$ & $\begin{array}{c}36 \\
(30.00)\end{array}$ & $\begin{array}{c}42 \\
(35.00)\end{array}$ & $\begin{array}{c}42 \\
(35.00)\end{array}$ \\
\hline 12 & $\begin{array}{l}\text { Use of synthetic pyrethroides (Cypermetherium } 10 \mathrm{ml} / 10 \text { lit } \\
\text { and Fenvelrate } 8 \mathrm{ml} / 10 \text { lit) and combination product(During } \\
\text { boll formation stage) }\end{array}$ & $\begin{array}{c}76 \\
(63.34)\end{array}$ & $\begin{array}{c}44 \\
(36.66)\end{array}$ & $\begin{array}{c}27 \\
(22.50)\end{array}$ & $\begin{array}{c}49 \\
(40.84)\end{array}$ & $\begin{array}{c}44 \\
(36.66)\end{array}$ \\
\hline
\end{tabular}

CA- Complete adoption PA- Partial adoption NA-No adoption 
Table.2 Distribution of respondents according to their level of overall knowledge and overall adoption of integrated pest management practices

\begin{tabular}{|c|c|c|c|c|c|}
\hline \multirow{2}{*}{$\begin{array}{c}\text { Sl. } \\
\text { No. }\end{array}$} & \multirow{2}{*}{ Index Level } & \multicolumn{4}{|c|}{ Respondents (n=120) } \\
\cline { 3 - 6 } & & \multicolumn{2}{|c|}{ Knowledge } & \multicolumn{2}{c|}{ Adoption } \\
\cline { 3 - 6 } & & Frequency & Percentage & Frequency & Percentage \\
\hline 1. & Low (Up to 33.33) & 03 & 02.50 & 09 & $\mathbf{0 7 . 5 0}$ \\
\hline 2. & Medium (33.34 to 66.66) & 67 & 55.84 & 103 & $\mathbf{8 5 . 8 4}$ \\
\hline 3. & High (Above 66.66) & 50 & 41.66 & 08 & $\mathbf{0 6 . 6 6}$ \\
\hline & Total & $\mathbf{1 2 0}$ & $\mathbf{1 0 0 . 0 0}$ & $\mathbf{1 2 0}$ & $\mathbf{1 0 0 . 0 0}$ \\
\hline & Mean & \multicolumn{3}{|c|}{$\mathbf{6 8 . 2 6}$} & \multicolumn{3}{|c|}{$\mathbf{1 3 . 2 2}$} \\
\hline
\end{tabular}

In case of non adopted integrated pest management practices were, selection of recommended variety with early medium maturity $(52.50 \%)$. It was also found that majority of respondents not adopted hand picking and destruction of larvae $(40.00 \%)$. It is also found that majority of the respondents not adopted use of trichocards (3cards/acre) i.e. for 7-8 times after the initiation of flowers at an interval 8-10 days (100.00\%). Most of the respondents did not adopted chemical method like use of synthetic pyrethroides (Cypermetherium $10 \mathrm{ml} / 10$ lit and Fenvelrate $8 \mathrm{ml} / 10 \mathrm{lit}$ ) and combination Product $(36.66 \%)$.

\section{Overall knowledge and adoption level}

Data presented in Table 2 shows that majority $(55.84 \%)$ of cotton growers had medium level of knowledge about integrated pest management practices, followed by 41.66 per cent in high and 2.50 per cent in low level respectively. These findings were consonance with the findings of Choudhari (2010), Sable and Kadam (2012), Patel and Sanwal (2015) and Raviya (2017), respectively.

Table 2 also revealed that majority $(85.84 \%)$ of cotton growers had medium level of adoption, followed by 07.50 per cent low and 06.66 per cent with high level of adoption of integrated pest management practices. These findings are supported byTilara (2009), Dhenge (2013) and Neethi and Shailaja (2013), respectively.

In conclusion, in order to accelerate the adoption of recommended technology of IPM for control of pink bollworm in cotton multifold efforts are needed. Extension agency of state Agriculture Department, Department of Agricultural Entomology, KVK functionaries and Zillha Parishad, Panchayt Samiti may jointly decide the policies and chalk out programmers for making IPM practices popular among the cotton growers to manage pink bollworm in cotton by resorting to the participatory approach so as to motivate and involve them in endeavor at hand.

\section{References}

Chaudhari M.B. 2010.Technological gap in cotton cultivation among the farmers of Vadodara District of Gujarat state. M.Sc. (Agri.) Thesis (Unpub.), AAU, Anand.

Dhenge S.A. 2013. Knowledge and adoption of integrated pest management practices by paddy growers. M.Sc. (Agri.) Thesis (Unpub.), Dr. PDKV, Akola.

Neethi and Sailaja, 2013. Extent of adoption of cotton production technologies by farmers in Andhra Pradesh. IJSR2(11); 21-24. 
Patel. M. R.andSanwal S., 2015. Knowledge of IPM practices among cotton growers of Sabarkantha district, Gujrat, India. International J. on Recent and Innovation Trends in Computing and Communication. 3(2): 444-446

Raviya P. B. 2017. Knowledge and adoption of farmers about cotton production practices recommended by GAU and JAU in Junagadh district. M.Sc. (Agri.) Thesis (Unpub.), Junagadh Agricultural University, Junagadh.
Sable B. D. and Kadam R. P. 2012. Adoption gap in integrated pest management technology of cotton. College of Agriculture, Marathvada Krishi Vidyapeeth, Parbhani. International Journal of Plant Protection. 5(2): 352355.

Tilara V.K.2009. Adoption of integrated pest management practices by $\mathrm{Bt}$ cotton growers, Gujarat state. M.Sc. (Agri.) Thesis (Unpub.), Anand agriculture university, Anand.

\section{How to cite this article:}

Shital Mane, P. P. Wankhade and Vaishali Rane. 2020. Adoption of Integrated Pest Management Practices for Control of Pink Bollworm by Cotton Growers. Int.J.Curr.Microbiol.App.Sci. 9(12): 2491-2495. doi: https://doi.org/10.20546/ijcmas.2020.912.294 